\title{
METAMORPHIC OLIVINE IN PICRITIC METAVOLCANICS FROM SOUTHERN FINLAND
}

\author{
PETRI PELTONEN
}

\begin{abstract}
PELTONEN, PETRI 1990. Metamorphic olivine in picritic metavolcanics from Southern Finland. Bull. Geol. Soc. Finland 62, Part 2, 99-114.

Metamorphic olivine occurs in magnesian ( $>18$ wt. \% $\mathrm{MgO}$ ) medium-Ti $\left(\mathrm{TiO}_{2}=1.0-2.0\right.$ wt. \%), mafic to ultramafic metapicritic rocks in the Early Proterozoic Svecofennian domain of Southern Finland. Relatively $\mathrm{Fe}_{2} \mathrm{SiO}_{4}$-rich porphyroblastic olivines formed in those rocks through decomposition of $\mathrm{Fe}-\mathrm{Mg}$ chloritedominated phyllosilicates at uppermost amphibolite facies conditions. Forsterite contents are, to some extent, related to bulk rock composition and abundances of coexisting phases. However, complex interactions dependent on modal compositions of the phyllosilicate assemblages being dehydrated and alteration processes which modified the phyllosilicate compositions were also controlling factors. These same factors are responsible for negative $\mathrm{OL}^{\mathrm{Ni}}$-Fo correlations observed in the metapicrites, opposite to those characteristic of olivines formed through fractional crystallization of magmas. Nickel contents of metamorphic olivines analyzed (290-3315 $\mathrm{ppm}$ ) cover the whole spectrum characteristic of igneous olivines. This wide range in olivine nickel contents is not due to Ni partitioning into a sulfide phase because only a very small amount of sulfide is present. Manganese contents in these metamorphic olivines are similar to those in igneous olivines and the very low calcium levels are characteristic of plutonic olivines. Caution is emphasized when utilizing olivine compositions for exploration purposes in regionally metamorphosed terrains.

Key words: metavolcanic rocks, picrite, olivine groups, petrography, electron probe data, Proterozoic, Rantasalmi, Western Uusimaa, Vammala, Finland
\end{abstract}

Petri Peltonen: Geological Survey of Finland, SF-02150, Espoo, Finland

\section{Introduction}

Metamorphic olivine is an important phase in medium to high grade assemblages of metamorphosed ultramafic rocks (e.g. Evans 1977). It is a common constituent of progressively metamorphosed serpentinites (Peretti et al. 1987, Kunugiza 1982, Vance and Duncan 1977, Tromsdorff and Evans 1974, Binns and Groves 1976) where it first forms through the metastable reaction crysotile $=$ antigorite + forsterite + vapour (Peretti et al. 1987) and at slightly higher grade by antigorite + brucite $=$ olivine + vapour
(Evans 1977). Olivine is thereafter stable in all prograde assemblages. Metamorphic olivine formed through dehydration reactions of serpentine minerals is anomalously Fo-rich (Pincent and Hirst 1975, Evans 1977, Vance and Duncan 1977, Kunugiza 1980, Papunen and Idman 1982, Dymek et al. 1988). The growth of this olivine does not affect magnetite, formed in the serpentinization process, thus ignoring most of the iron previously present in the igneous olivine characteristic for that rock composition. Forsterite contents exceeding $95 \mathrm{~mol} . \%$ are not uncommon for olivines formed through such a process (Evans 
1977). Magnetite is often seen as droplet-shaped inclusions or tracks in metamorphic olivine that are remnants from the serpentinite protolith and mimic original grain boundaries.

Metamorphic olivine can also form from phyllosilicates other than serpentine. In WestAustralian metakomatiites, relatively Fe-rich porphyroblastic olivine selectively replaced chlorite which itself was a replacement-product of spinifex-textured olivine (Oliver et al. 1972). These authors argued that the high iron-content of this chlorite had lowered its breakdown temperature and facilitated the crystallization of olivine at amphibolite facies (Turnock 1960). In contrast, Stamatelopoulou-Seymour and Francis (1980) argued that Fo-poor olivine porphyroblasts in peridotitic metakomatiites were not formed by chlorite breakdown reactions. They proposed the reaction serpentine + diopside $=$ forsterite + tremolite + vapour responsible for the equilibrium mineral assemblage olivinetremolite-serpentine-chlorite \pm talc. Clearly, processes which govern the growth of relatively iron-rich olivine in highly magnesian rocks have not been resolved satisfactorily.

This paper, for the first time describes relatively $\mathrm{Fe}_{2} \mathrm{SiO}_{4}$-rich metamorphic olivines found in metapicritic rocks. Host rocks were metamorphosed to low pressure upper amphibolite facies conditions during the Svecokarelidic orogeny. They are less magnesian and more silica-rich than metaserpentinites and metakomatiites from which metamorphic olivine has been reported earlier. Compositional trends distinct from igneous olivine are discussed with special reference to trace element contents.

\section{Geological setting}

Supracrustal rocks of southern Finland belong to the Svecofennian domain of the Svecokarelidic orogeny, 1.90-1.83 Ga in age (Huhma 1986, Kähkönen 1989). The Svecofennides are interpreted to have formed through sequential accretion of island arcs (e.g. Gaál 1990), although also a more complicated history has been postulated (Nironen 1989). Svecofennian volcanism was dominantly calc-alkalic with some tholeiitic material (e.g. Mäkelä 1989) and rare ultramafic volcanic rocks, sometimes together with mafic volcanics within metapelites. Svecofennian volcanism took place between 1.90 and $1.87 \mathrm{Ga}$ (Huhma 1986) although there is evidence that some of the basaltic volcanics might be older (around $1.99 \mathrm{Ga}$ ) and might represent allochtonous slabs of oceanic crust accreted to the Svecofennian terrain (Vaasjoki and Huhma 1987).

Ultramafic and mafic metavolcanics were sampled from Rantasalmi, West-Uusimaa and Vammala regions (Fig. 1). Sampling was guided by earlier descriptions from Rantasalmi by Kousa (1985), from West-Uusimaa by Schreurs and Westra (1985) and from Vammala by Häkli et al. (1979) and Mäkinen (1987). Mineral assemblages are metamorphic with no preservation of primary minerals except some phenocrysts in the Vammala area. Chemically, the rocks are »highMg» metavolcanics, which according to IUGS recommendations (Le Maitre 1989), can be broadly classified as picritic rocks. This subclass includes all volcanic rocks having $\mathrm{MgO}>18$ wt. $\%, \mathrm{SiO}_{2}<53$ wt. $\%$ and $\mathrm{Na}_{2} \mathrm{O}+\mathrm{K}_{2} \mathrm{O}<2.0$ wt. $\%$ on an anhydrous basis. However, upper parts of some the differentiated single flows have less than $18 \mathrm{wt} \% \mathrm{MgO}$. The range of silica contents is relatively large (Table 1) and in some flows $\mathrm{SiO}_{2}$ exceeds 45 wt. \% (anhydrous) even in the most magnesian (up to 25 wt. $\% \mathrm{MgO}$ ) bottom units. These Svecofennian metapicrites are more differentiated with respect to Ti compared to true komatiites (Table 1). Normative compositions are peridotitic and always silicaundersaturated containing olivine \pm nepheline. Differentiation trends were largely determined by fractionation of olivine and orthopyroxene.

Metavolcanics of the Rantasalmi area, close to the Archean-Proterozoic suture zone in southeastern Finland, constitute a differentiated suite of mafic (amphibolites) to ultramafic (amphiboleolivine rocks) lava flows and pyroclastic and lava 

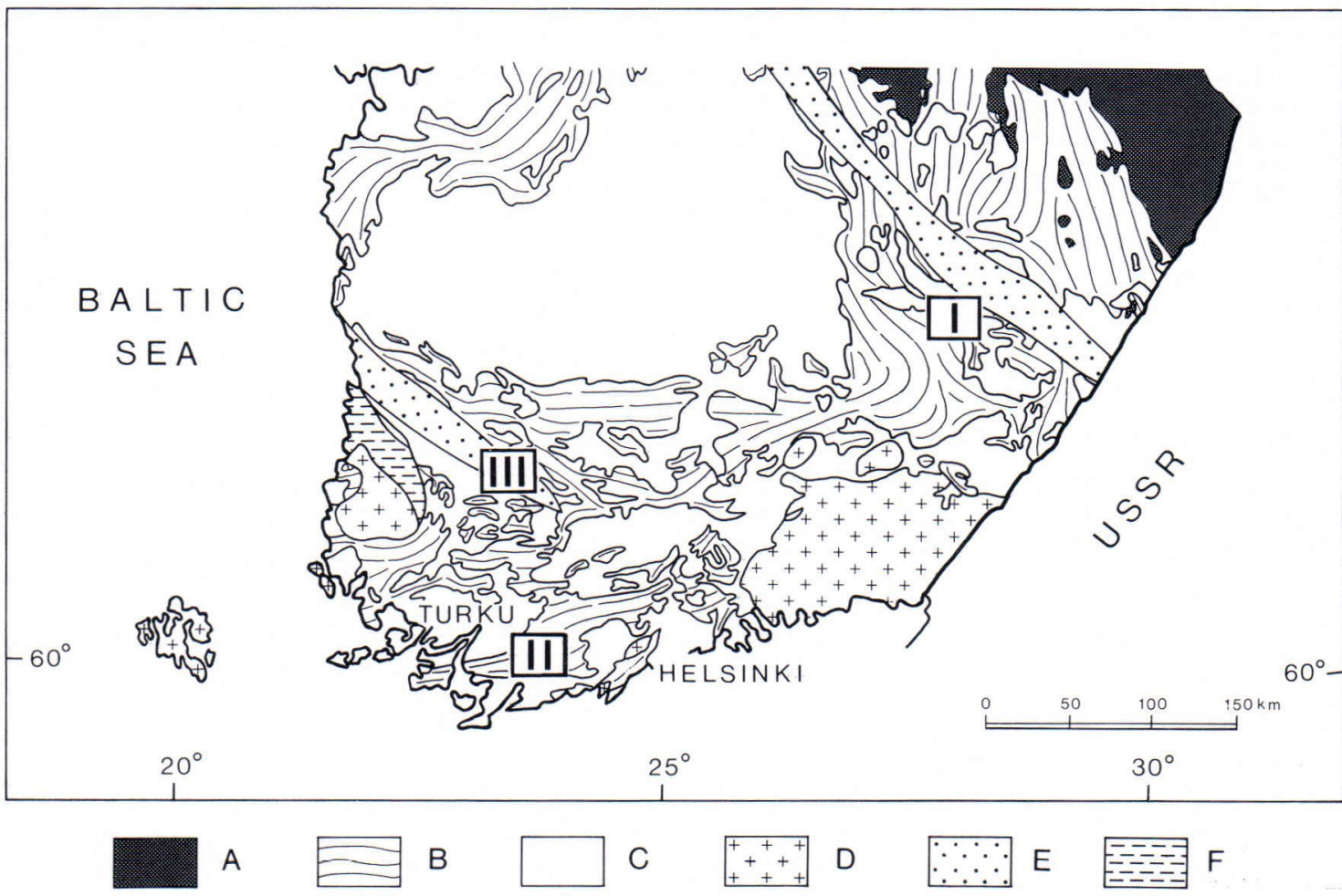

Fig. 1. Major geological units of southern Finland and locations of »high-Mg» metavolcanics. A: Archaean; B: Early Proterozoic schist belts, migmatites; C: Granitoids; D: Rapakivi granites; E: Nickel belts; F: Postsvekokarelidian supracrustal rocks; I: Rantasalmi; II: West-Uusimaa; III: Vammala. Modified from Simonen (1980) and Mäkinen (1987).

breccias. Pillow and amygdaloidal structures point to a subaqueous environment (Kousa 1985). The mineralogy of the ultramafic members is characterized by large olivine porphyroblasts, colourless tremolitic hornblende, clinopyroxene and porphyrobiastic green spinel $( \pm$ chlorite, \pm carbonate). These form a stable metamorphic assemblage characteristic of upper amphibolite facies (Evans 1977). Potassium feldspar-sillimanite assemblages in the adjacent metapelites give metamorphic crystallization condition estimates of $660^{\circ} \mathrm{C}$ and 4 kbars (Korsman 1977). These temperatures and pressures are consistent with the absence of orthopyroxene in the Rantasalmi ultramafic rocks.

An almost identical sequence of subaqueous, pillow-structured (Schreurs et al. 1986) ultramafic picritic volcanics occur within metapelites in the
West-Uusimaa region, Southern Finland (Fig. 1). This southernmost Svecofennian supracrustal zone may represent a rift environment characterised by bimodal volcanism within the Svecofennian paleo-island-arc (Mäkelä 1989). Ultramafic metavolcanics occur close to and inside the granulite facies West-Uusimaa Complex (Parras 1958, Schreurs and Westra 1986). Metamorphic conditions reached $750^{\circ} \mathrm{C}-825^{\circ} \mathrm{C}$ and 3-5 kbars (Screurs and Westra 1986). Compositions of West-Uusimaa amphibolites and ultramafic lava flows form continuous geochemical trends pointing towards a common parental magma (Schreurs et al. 1986). Stable mineral assemblages here comprise metamorphic olivine, magnesiohornblende, diopside or orthopyroxene and green spinel. The occurence of metamorphic orthopyroxene at West-Uusimaa and amphibole 
Table 1. Representative whole rock analyses of Svekofennian ultramafic metavolcanic rocks. 1-2. Rantasalmi, 3-4. WestUusimaa, 5-6. Vammala. 7.: weighted mean composition of the lowermost differentiated picritic flow from Uusiniitty occurrence (Vammala). Analyses 1-6. by the geochemical laboratory at the Geological Survey of Finland, Espoo; 7 . calculated from unpublished analyses of Outokumpu Ltd Exploration. Total iron calculated as $\mathrm{Fe}_{2} \mathrm{O}_{3}$; n.d. = analysed but not detected. Major elements are reported in wt. $\%$ and trace elements in ppm.

\begin{tabular}{|c|c|c|c|c|c|c|c|}
\hline Sample & 1 & 2 & 3 & 4 & 5 & 6 & 7 \\
\hline $\mathrm{SiO}_{2}$ & 35.89 & 42.72 & 43.66 & 40.16 & 40.31 & 42.48 & 47.78 \\
\hline $\mathrm{TiO}_{2}$ & 1.07 & 0.81 & 1.38 & 0.93 & 1.30 & 1.63 & 0.84 \\
\hline $\mathrm{Al}_{2} \mathrm{O}_{3}$ & 9.40 & 8.16 & 7.63 & 6.65 & 7.68 & 7.63 & 8.22 \\
\hline $\mathrm{Fe}_{2} \mathrm{O}_{3} *$ & 15.05 & 11.29 & 13.89 & 15.97 & 14.77 & 15.08 & 11.69 \\
\hline $\mathrm{MnO}$ & 0.22 & 0.16 & 0.19 & 0.20 & 0.18 & 0.18 & 0.19 \\
\hline $\mathrm{MgO}$ & 19.76 & 21.72 & 19.95 & 25.27 & 16.51 & 18.48 & 17.16 \\
\hline $\mathrm{CaO}$ & 10.74 & 8.62 & 8.89 & 4.91 & 14.66 & 9.41 & 10.79 \\
\hline $\mathrm{Na}_{2} \mathrm{O}$ & 0.16 & 0.16 & 0.77 & 0.13 & 0.29 & 1.08 & 1.45 \\
\hline $\mathrm{K}_{2} \mathrm{O}$ & 0.04 & 0.06 & 0.19 & 0.04 & 0.03 & 0.24 & 0.51 \\
\hline $\mathrm{P}_{2} \mathrm{O}_{5}$ & 0.10 & 0.08 & 0.11 & 0.10 & 0.16 & 0.20 & 0.17 \\
\hline $\mathrm{H}_{2} \mathrm{O}_{\text {tot }}$ & 5.60 & 5.30 & 2.10 & 6.10 & 1.20 & 3.40 & - \\
\hline S & 0.02 & 0.02 & 0.02 & 0.18 & 0.02 & 0.07 & - \\
\hline $\mathrm{C}_{\text {tot }}$ & 0.55 & n.d. & 0.05 & 0.06 & 0.33 & 0.05 & - \\
\hline Total & 98.60 & 99.10 & 98.83 & 100.70 & 97.44 & 99.93 & 98.79 \\
\hline $\mathrm{Zr}$ & 57 & 52 & 82 & 63 & 81 & 106 & \\
\hline $\mathrm{Nb}$ & 6 & 4 & 9 & 5 & 15 & 23 & \\
\hline $\mathrm{Rb}$ & 4 & 5 & 15 & n.d. & 5 & 6 & \\
\hline $\mathrm{Sr}$ & 199 & 109 & 124 & 40 & 130 & 194 & \\
\hline $\mathrm{Y}$ & 16 & 10 & 12 & 10 & 9 & 16 & \\
\hline $\mathrm{Ba}$ & 32 & 37 & 20 & 28 & 62 & 272 & \\
\hline $\mathrm{Ni}$ & 1164 & 812 & 952 & 1602 & 1454 & 982 & \\
\hline $\mathrm{Cu}$ & 91 & n.d. & n.d. & 129 & 76 & 101 & \\
\hline $\mathrm{Zn}$ & 155 & 68 & 108 & 139 & 115 & 114 & \\
\hline $\mathrm{Cr}$ & 2081 & 1241 & 1369 & 1562 & 2315 & 1747 & \\
\hline
\end{tabular}

compositions that have lower calculated Sications (Evans 1982) suggest that metamorphic temperatures were higher at West-Uusimaa than at Rantasalmi.

The third occurrence of Svecofennian »high$\mathrm{Mg}$ » extrusive rocks is located in the Vammala nickel belt, where picritic lavas and some pyroclastic rocks are intermingled with pelitic sediments. These rocks have also been called "cortlandites" in which agglomeratic textures have been reported (Häkli et al. 1979). Drill core profiles show that each flow unit is composed multiple differentiated flows. Metamorphic olivine is found only in the most magnesian lower parts of each flow where normative olivine contents approach $40 \%$. Mineral assemblages (metamorphic olivine, tschermakitic/magnesio hornblende, diopside or orthopyroxene, green spinel \pm carbonate) correspond to those determined from surrounding upper amphibolite - lower granulite facies metapelites $\left(\approx 670^{\circ} \mathrm{C}\right.$ and $5-6$ kbars; P. Hölttä, unpubl. data). These picritic rocks of the Vammala nickel belt do not contain sulfide mineralizations, which are mostly restricted to strongly serpentinized, peridotitic silltype bodies emplaced during the Svecokarelidic orogeny (Peltonen and Korsman 1990). The genetic relationship between nickel sulfide bearing peridotites and picritic rocks in the Vammala nickel province is outside the scope of this paper and will be described elsewhere.

\section{Petrography of porphyroblastic olivine}

Metamorphic olivine occurs as large irregularshaped porphyroblasts with highly embayed margins (Fig. 2). Porphyroblasts may also engulf 
Fig. 2. Slightly serpentinized embayed olivine porphyroblast in amphibolite. $\mathrm{Ol}=$ olivine; $\mathrm{Hb}=$ hornblende; $\mathrm{Lz}=$ lizardite. Vammala locality, crossed nicols.

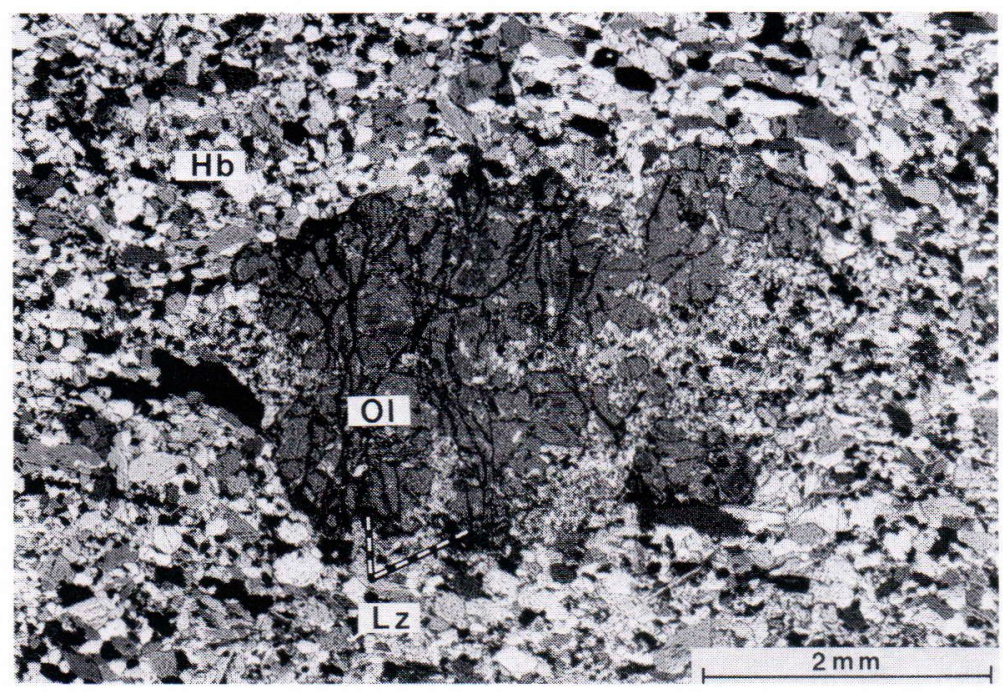

Fig. 3. Olivine (Ol)-hornblendediopside (Di)-carbonate (Crb)-green spinel (GSpi) assemblage. In the carbonate host, olivine and spinel (black) exhibit idioblastic morphology. Rantasalmi locality, crossed nicols.

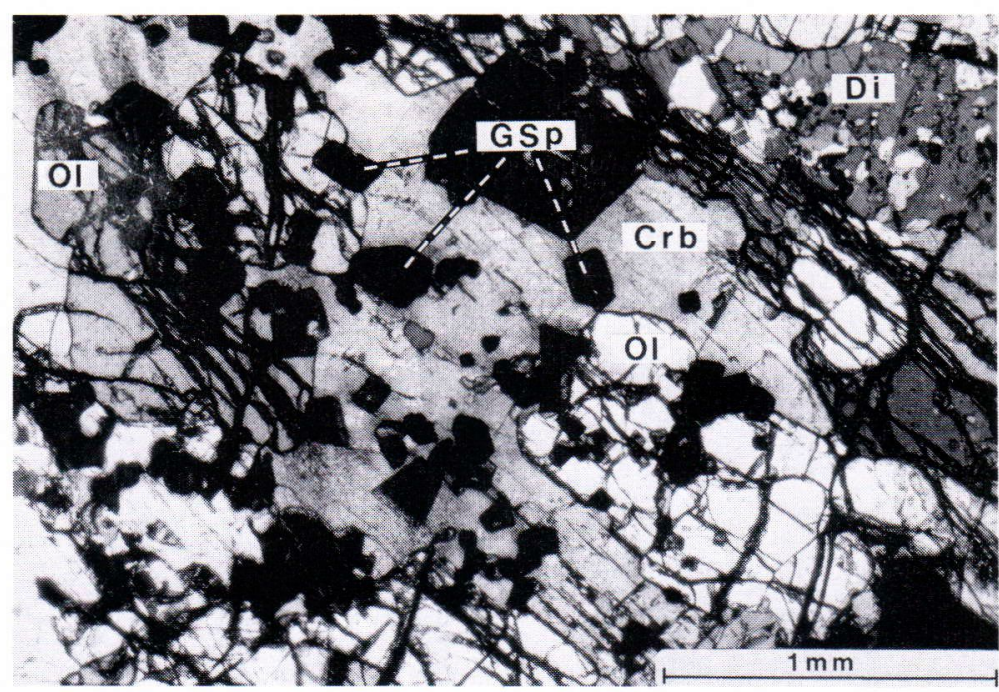

needlelike amphibole nematoblasts. The porphyroblasts range in size from millimeters to several centimeters and are elongated in the direction of the main schistosity $\left(\mathrm{S}_{2}\right)$. Only minor extinction undulation at the scale of entire blasts is evident, especially in West-Uusimaa, and suggests that only a limited amount of strain was involved during crystallization. In the Rantasalmi area where carbonate is locally present as a stable mineral, the morphology of metamorphic olivine may be idioblastic (Fig. 3), with crystal faces in rare cases coinciding with the cleavage pattern of the carbonate host. Amphibole, chlorite spinel and magnetite inclusions are abundant, clearly indicating a metamorphic origin. In the WestUusimaa region, olivines are full of minute, subparallel amphibole needles $5-100 \mu \mathrm{m}$ in length (Fig. 4). Binns and Champness (1985) have reported a similar texture in relict igneous olivines from ultramafic rocks in the Yilgarn block, Australia. They regarded this as an exsolution texture and explained that tremolite, together with 

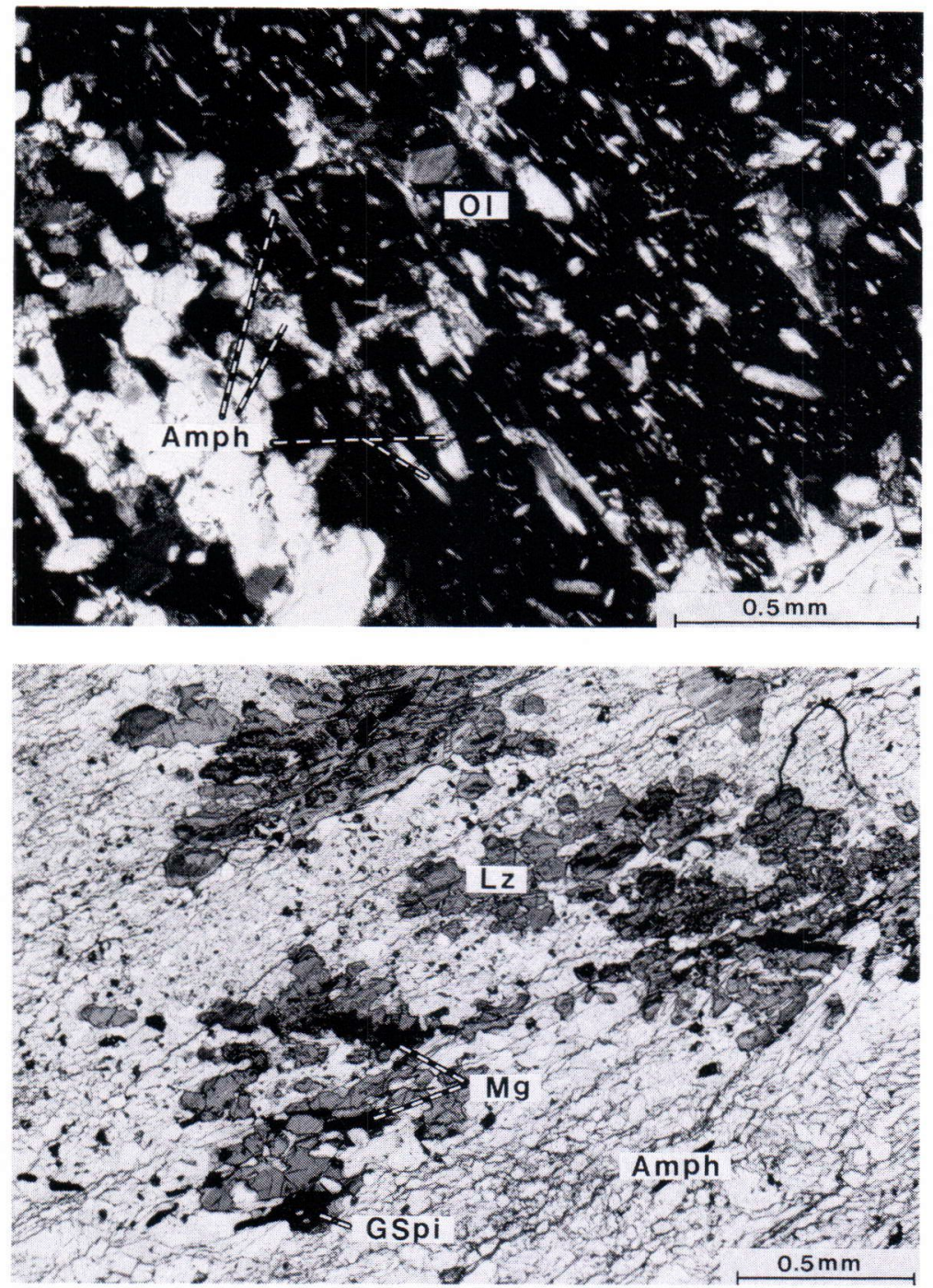

Fig. 4. Large sieve-textured olivine porphyroblast (in extinction) hosting numerous subparallel amphibole inclusions. West-Uusimaa locality. Amph $=$ amphibole $\mathrm{Ol}=$ Olivine.
Fig. 5. Pseudomorphs of olivine porphyroblasts (now lizarlite) oriented parallel to the main schistosity $\left(\mathrm{S}_{2}\right)$. $\mathbf{L z}=$ lizarlite; Amph = amphibole; GSpi = green spinel; $\mathrm{Mg}=$ magnetite. Rantasalmi locality, one nicol. diopside, chlorite and antigorite formed from igneous olivine during metamorphism by reactions involving limited diffusion of water and oxygen. In the West-Uusimaa olivines, however, the amphibole needle orientation is far less pronounced and not strictly governed by any crystallographic directions. Additionally, similar amphibole needles occur in poikiloblastic orthopyroxene coexisting with olivine. Matrix amphibole, in contrast, exhibits an annealed granoblastic texture. Therefore an exsolution origin for these am- phibole needles is unlikely. More likely they are simply inclusions with orientations controlled by an early schistosity.

Low temperature retrograde serpentinization and weathering has led to poorly crystalline serpentine pseudomorphs after metamorphic olivine. Colourless or yellowish serpentine together with reddish iddingsite replaces olivine along fractures and rims of porphyroblasts. Polygonal mesh texture, which is the most common olivine alteration texture (e.g. Wicks et al. 1977) is only 
Table 2. A proposed morphological classification of metamorphic olivines in mafic to ultramafic rocks.

\begin{tabular}{|c|c|c|}
\hline MORPHOLOGY & ROCK ASSOCIATION & REFERENCES \\
\hline \multirow{2}{*}{$\begin{array}{l}\text { Porphyroblastic } \\
\text { Sieve-textured, ragged, } \\
\text { embayed }\end{array}$} & & \\
\hline & $\begin{array}{l}\text { Tremolite-chlorite rocks } \\
\text { (komatiitic and picritic rocks) }\end{array}$ & $\begin{array}{l}\text { Oliver et al. } 1972 \\
\text { Stematelopoulou-Seymour } \\
\text { and Francis } 1980 \\
\text { Warner et al. } 1989 \\
\text { Blais and Auvrey } 1990 \\
\text { This study }\end{array}$ \\
\hline Idiomorphic & $\begin{array}{l}\text { Metaserpentinites, } \\
\text { Skarns, other carbonate-bearing } \\
\text { assemblages }\end{array}$ & $\begin{array}{l}\text { Frost } 1975 \\
\text { Vance and Duncan } 1977 \\
\text { Peretti et al. } 1987 \\
\text { This study }\end{array}$ \\
\hline $\begin{array}{l}\text { Elongate, bladed, needlelike } \\
\text { (»Jackstraw-texture») }\end{array}$ & $\begin{array}{l}\text { Talc-olivine rocks } \\
\text { Olivine-sulphide intergrowths } \\
\text { Dolomites (»ophidolomite» -texture) \& } \\
\text { magnesite-rocks }\end{array}$ & $\begin{array}{l}\text { Evans and Trommsdorff } 1974 \\
\text { Hietanen } 1976 \\
\text { Binns \& Groves } 1976 \\
\text { Collerson \& Jesseau } 1976 \\
\text { Snoke and Calk } 1978 \\
\text { Papunen \& Idman } 1982 \\
\text { Nilsson 1985 } \\
\text { Hill et al. } 1988\end{array}$ \\
\hline
\end{tabular}

locally evident. Magnetite has formed from the excess iron. Even after complete serpentinization, the rosette-like outlines of metamorphic olivine are still evident (Fig. 5).

\section{Morphological classification of metamorphic olivines}

In this study it is suggested that the term metamorphic olivine should only be used for olivines clearly recrystallized through dehydration reactions from hydrous parent minerals. Neoblastic olivines (Mercier and Nicolas 1975) which are strain-free, equigranular and deformationinduced olivine grains that occur together with porphyroclastic igneous olivine grains in mantle peridotites are thus excluded in this classification. Paktunc (1984) had described neoblasts developed along dislocation planes of olivine in metamorphosed ultramafic rocks from Thompson mine, Manitoba. Although the Thompson mine neoblasts were slightly enriched in $\mathrm{Ni}$ and Mn relative to parental olivine, they clearly inherited their composition from parental olivine in a very different way than true metamorphic olivines formed through dehydration reactions.

A simple morphological subdivision of metamorphic olivines is proposed in table 2 . It is based strictly on crystal morphology and does not stress the olivine-forming dehydration reactions. To some extent the subdivision of porphyroblastic and elongate olivine is arbitrary. Evans and Tromsdorff (1974) pointed out that the elongation of metamorphic olivine is parallel to the direction [010], while the magmatic spinifex olivines are elongated in the [001] direction. All the olivines described in this study are sieve-textured, embayed and idiomorphic porphyroblasts.

\section{Metamorphic crystallization}

In the Finnish metapicritic rocks the stable olivine bearing mineral assemblages are A) olivine - hornblende - green spinel, B) olivine - hornblende - orthopyroxene - green spinel and C) olivine - hornblende - diopside - carbonate - green spinel \pm chlorite. These assemblages are characteristic of upper amphibolite and lower granu- 
lite facies (Evans 1977). The dehydration of $\mathrm{Mg}$ chlorite occurs at $750-775^{\circ} \mathrm{C}$ between $4-6$ kbars $\left(\mathrm{P}_{\text {tot }}=\mathrm{P}_{\mathrm{H}_{2} \mathrm{O}}\right)$ through the reaction chlorite $=$ olivine +2 orthopyroxene + spinel +4 $\mathrm{H}_{2} \mathrm{O}$ (Fawcett and Yoder 1966, Evans 1977, Jenkins 1981, Jenkins and Chernosky 1986) and is likely to be responsible for these assemblages. Green spinel never occurs in thin sections without metamorphic olivine which strongly supports their origin through the reaction shown above. Carbonate bearing assemblage $\mathrm{C}$ ) is encountered in the lower temperature Rantasalmi region. Assemblage $\mathrm{C}$ ) may have formed through the reaction 3 chlorite +2 calcite $=5$ olivine +2 diop side +3 spinel $+12 \mathrm{H}_{2} \mathrm{O}+2 \mathrm{CO}_{2} \cdot \mathrm{X}_{\mathrm{Co} 2}$ was probably low since at $\mathrm{X}_{\mathrm{CO} 2}>0.4$ and at temperatures determined from adjacent metapelites $\left(660^{\circ} \mathrm{C}\right.$, Korsman 1977$)$, orthopyroxene would be present in assemblages where olivine and spinel are stable (Lieberman and Rice 1986).

\section{Mineral chemistry}

The mineral determinations were carried out at the Department of Electron Optics at Univer- sity of Oulu, using a JEOL JCXA 733 microprobe. Natural and synthetic oxides and metals were used as standards. The detection limits for all elements analyzed are close to 0.01 wt. \%. Data reduction was done by an on-line ZAF correction program. Sample current was 33 $\mathrm{nA}$ at an acceleration potential of $15 \mathrm{kV}$. The methods have been explained in more detail by Alapieti and Sivonen (1983). Forsterite content of olivine has been calculated from mineral formula according to $\mathrm{Fo}(\mathrm{mol} . \%)=100 \times \mathrm{Mg} /$ $(\mathrm{Mg}+\mathrm{Fe})$.

\section{Major elements}

The forsterite content of Finnish metapicrite olivine porphyroblasts has a large range compared to whole rock compositions. Olivine varies from $60.5-76.0$ mol. \% Fo (Table 3) with a mean of $\mathrm{Fo}_{69.5}$, while whole rock $\mathrm{Mg} / \mathrm{Mg}+\mathrm{Fe}_{\text {tot }}$ varies from 0.73 to 0.81 . Olivines in the Rantasalmi and West-Uusimaa regions form a compositionally tighter group $\left(\mathrm{Fo}_{64.6-75.9}\right)$ than olivines analyzed from the Vammala region $\left(\mathrm{Fo}_{60.5-76.0}\right)$. This is despite the fact that Rantasalmi and WestUusimaa regions represent the lowest and highest

Table 3. Microprobe analyses of porphyroblastic olivines. 1-5. Rantasalmi, 6-11. West-Uusimaa, 12-17. Vammala. * = Mean of two analysis by Schreurs et al. (1986).

\begin{tabular}{|c|c|c|c|c|c|c|c|c|c|c|c|c|c|c|c|c|c|}
\hline Sample & 1 & 2 & 3 & 4 & 5 & 6 & 7 & 8 & 9 & 10 & $11^{*}$ & 12 & 13 & 14 & 15 & 16 & 17 \\
\hline $\mathrm{SiO}_{2}$ & 36.99 & 37.11 & 38.39 & 38.14 & 37.80 & 36.71 & 36.85 & -36.88 & 36.69 & 38.35 & 37.90 & 34.81 & 35.95 & 36.10 & 37.66 & 38.11 & 37.95 \\
\hline $\mathrm{FeO}$ & 27.75 & 29.45 & 25.29 & 25.46 & 24.67 & 30.54 & 29.42 & 28.93 & 29.77 & 22.51 & 23.65 & 31.45 & 32.04 & 33.78 & 23.40 & 22.10 & 21.85 \\
\hline $\mathrm{MgO}$ & 33.70 & 34.22 & 36.84 & 36.10 & 36.44 & 31.38 & 32.45 & 33.33 & 33.11 & 39.84 & 37.53 & 27.98 & 29.44 & 29.00 & 37.90 & 39.16 & 38.84 \\
\hline $\mathrm{CaO}$ & 0.04 & 0.01 & 0.02 & 0.00 & 0.02 & 0.00 & 0.01 & 0.00 & 0.02 & 0.00 & 0.02 & 0.03 & 0.02 & 0.02 & 0.01 & 0.00 & 0.03 \\
\hline $\mathrm{MnO}$ & 0.42 & 0.40 & 0.38 & 0.37 & 0.41 & 0.40 & 0.34 & 0.38 & 0.33 & 0.29 & 0.36 & 0.44 & 0.43 & 0.45 & 0.53 & 0.27 & 0.23 \\
\hline $\mathrm{NiO}$ & 0.19 & 0.22 & 0.16 & 0.14 & 0.26 & 0.21 & 0.24 & 0.18 & 0.18 & 0.12 & 0.29 & 0.32 & 0.42 & 0.40 & 0.14 & 0.07 & 0.04 \\
\hline Total & 99.09 & 101.41 & 101.08 & 100.21 & 99.60 & 99.24 & 99.31 & 99.70 & 100.10 & $1 \mathrm{Cl} .11$ & 99.75 & 95.03 & 98.30 & 99.75 & 99.64 & 99.71 & 98.94 \\
\hline Ox & 4 & 4 & 4 & 4 & 4 & 4 & 4 & 4 & 4 & 4 & 4 & 4 & 4 & 4 & 4 & 4 & 4 \\
\hline $\mathrm{Si}$ & 1.000 & 0.987 & 1.002 & 1.005 & 1.000 & 1.004 & 1.002 & 0.996 & 0.991 & 0.988 & 0.997 & 1.007 & 1.003 & 1.000 & 0.991 & 0.994 & 0.996 \\
\hline $\mathrm{Fe}$ & 0.627 & 0.655 & 0.552 & 0.561 & 0.546 & 0.699 & 0.669 & 0.653 & 0.673 & 0.485 & 0.520 & 0.761 & 0.748 & 0.783 & 0.515 & 0.482 & 0.480 \\
\hline $\mathrm{Mg}$ & 1.358 & 1.357 & 1.433 & 1.418 & 1.438 & 1.279 & 1.315 & 1.342 & 1.333 & 1.530 & 1.472 & 1.206 & 1.225 & 1.198 & 1.487 & 1.523 & 1.520 \\
\hline $\mathrm{Ca}$ & 0.001 & 0.000 & 0.001 & 0.000 & 0.001 & 0.000 & 0.000 & 0.000 & 0.001 & 0.000 & 0.001 & 0.001 & 0.001 & 0.001 & 0.000 & 0.000 & 0.001 \\
\hline $\mathrm{Mn}$ & 0.010 & 0.009 & 0.008 & 0.008 & 0.009 & 0.009 & 0.008 & 0.009 & 0.008 & 0.006 & 0.008 & 0.011 & 0.010 & 0.011 & 0.012 & 0.006 & 0.005 \\
\hline $\mathrm{Ni}$ & 0.004 & 0.005 & 0.003 & 0.003 & 0.006 & 0.005 & 0.005 & 0.004 & 0.004 & 0.002 & 0.006 & 0.007 & 0.009 & 0.009 & 0.003 & 0.001 & 0.001 \\
\hline Fo & 68.403 & 67.441 & 72.197 & 71.652 & 72.475 & 64.685 & 66.287 & 67.253 & 66.472 & 75.933 & 73.882 & 61.329 & 62.092 & 60.480 & 74.275 & 75.954 & 76.012 \\
\hline Cat & 3.000 & 3.013 & 2.998 & 2.995 & 3.000 & 2.996 & 2.998 & 3.004 & 3.009 & 3.012 & 3.003 & 2.993 & 2.997 & 3.000 & 3.009 & 3.006 & 3.004 \\
\hline
\end{tabular}


metamorphic grades, respectively. It is apparent that $\mathrm{Fe}-\mathrm{Mg}$ distribution was not controlled by the P-T conditions but rather by whole rock compositions and other factors discussed later.

In magmatic systems olivine $F_{0}$ is a function of $\mathrm{MgO} / \mathrm{FeO}$ of the coexisting liquid. Because the iron content of ultramafic magmas does not change much during the fractionation of magnesian olivines and the $\mathrm{KD}_{(\mathrm{Fe}-\mathrm{Mg})}$ between olivine and liquid is known, the composition of olivine in equilibrium with certain magnesian liquids can be calculated (Roeder and Emslie 1970, Bickle 1982). The mean magnesium content of picritic rocks from the Rantasalmi and West-Uusimaa occurrences is 21.9 wt. $\%$ and 20.4 wt. $\% \mathrm{MgO}$ (volatile free), respectively. In light of the suba- quaous pillow structures of the Rantasalmi (Kousa 1985) and West-Uusimaa (Schreurs et al. 1986) metavolcanics, these mean values could be close to the original liquid compositions although minor fractionation within pillows or within the preeruptive magma chamber could have occurred. From the Vammala occurrences where pillow structures do not occur, weighted mean compositions of single differentiated flows have been calculated (Table 1). No low-Mg volcanic rocks belong to the succession in the Vammala nickel belt. Extrusive magmas with magnesium contents deduced above should crystallize olivine of about $\mathrm{Fo}_{90}$ as a first liquidus phase (Duke and Naldrett 1978). It is evident that the metamorphic olivines analyzed are anomalously iron-rich compared to

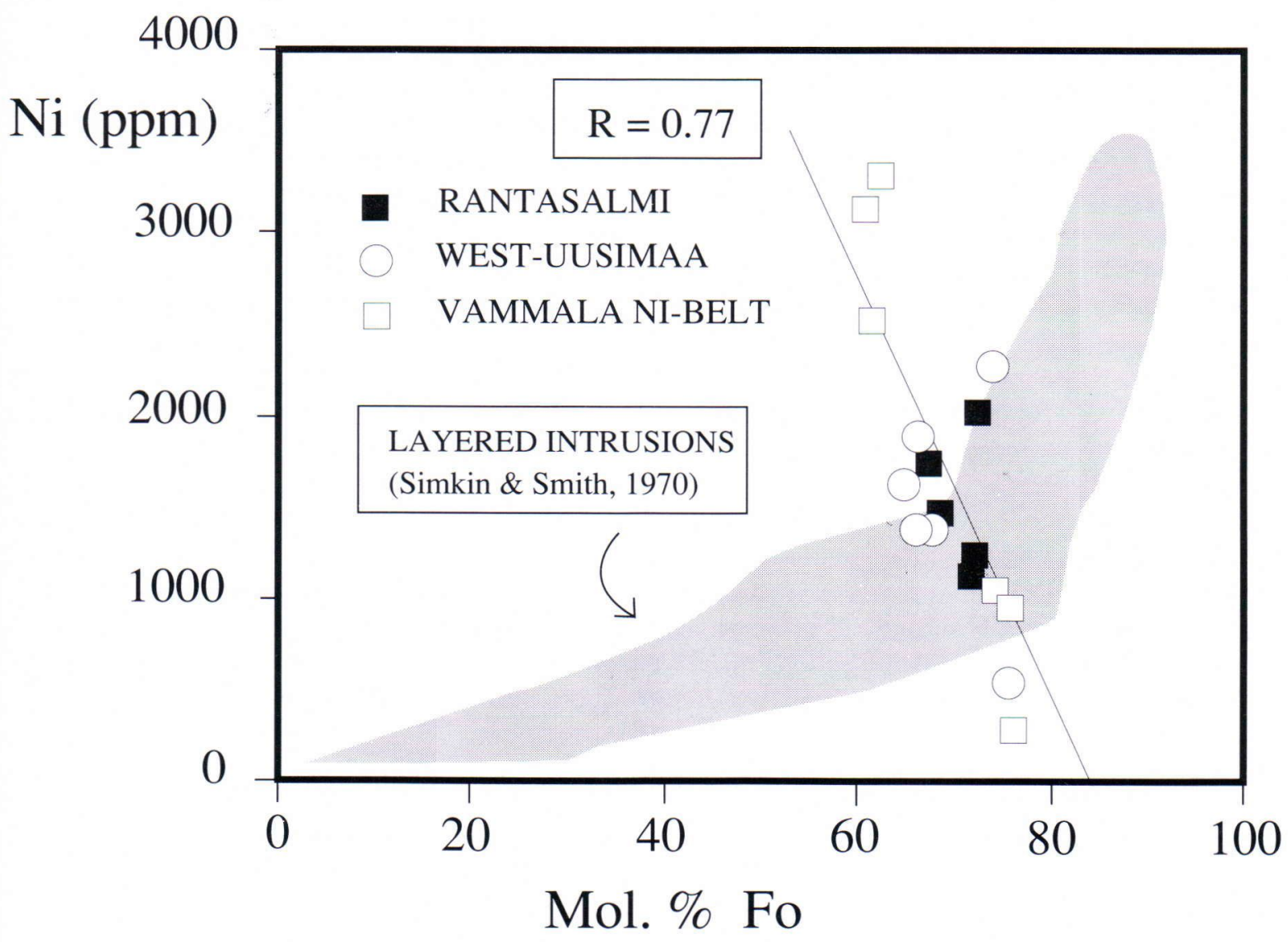

Fig. 6. Variation of nickel with forsterite in porphyroblastic olivines in Svecofennian metapicritic rocks. Shaded field defines the range of »normal igneous olivines» according to Simkin and Smith (1970). Modified from Thompson and Naldrett (1984). 
their host rock compositions. In fact, forsterite contents of porphyroblastic olivines measured are characteristic for igneous olivines in equilibrium with normal basaltic to andesitic liquids (Simkin and Smith 1970). Pyroclastic, subaqueous (Häkli et al. 1979, Kousa 1985, Schreurs et al. 1986) or flow textures are evident in all three Finnish metapicrite localities arguing against the possibility that the ultramafic rocks were cumulates of basaltic to andesitic magmas.

\section{Trace elements}

Nickel

Nickel contents in these olivine porphyroblasts show an exceptionally wide range, from $290 \mathrm{ppm}$ to $3315 \mathrm{ppm}$ and averaging $1648 \mathrm{ppm}$. Figure 6 shows the variation of $\mathrm{Ni}$ with forsterite content in porphyroblastic olivines. The shaded field is the compositional range of "normal» igneous olivines as tabulated by Thompson and Naldrett (1984) according to Simkin and Smith (1970). Some of the porphyroblastic olivines plot above this field and can be classified as "anomalous» relative to their iron and/or nickel contents. Table 4 is a correlation matrix of five variables: $\mathrm{Fe}$, $\mathrm{Mg}, \mathrm{Mn}$, Ni content of mineral formula and $\mathrm{Mg} /(\mathrm{Mg}+\mathrm{Fe})$, calculated for the porphyroblastic olivines. Ni correlates negatively with the $\mathrm{Mg}$ $(r=-0.809)$, but positively with $\mathrm{Fe}(\mathrm{r}=0.770)$. This is opposite to magmatic systems where olivine nickel correlates positively with $\mathrm{Mg}$ content as a result of preferential removal of $\mathrm{MgO}$ and $\mathrm{Ni}$ by olivine crystallization. In the porphyroblastic olivines analyzed, substitution of $\mathrm{Fe}$ by $\mathrm{Ni}$ is evident. This is exceptional because Ni-Mg substitution is expected to dominate due to the similar sizes of $\mathrm{Mg}$ and $\mathrm{Ni}$ ions (Brown 1980) and complete solid solution in the system $(\mathrm{Mg}, \mathrm{Ni})_{2} \mathrm{SiO}_{4}$ (Rajamani et al. 1975). Furthermore, clear Ni-Fo anticorrelations require that these metamorphic olivines have not equilibrated with sulfide or talc which strongly partition Ni relative to olivine.

\section{Manganese and calcium}

Mn contents in the Finnish metapicritic olivines do not show very significant correlation with other elements (Table 4). However, with $95 \%$ probability, the Mn-Fe $(r=0.584)$ and $\mathrm{Mn}-\mathrm{Ni}(r=$ $0.599)$ correlations are meaningful. In igneous olivines $\mathrm{Mn}-\mathrm{Fe}$ correlation is also positive but stronger (Simkin and Smith, 1970) because manganese is strongly related to major element fractionation. Relative to igneous olivines total concentrations of $\mathrm{Mn}$ in porphyroblasts are not anomalous. The manganese content of olivines in this study varies between $0.23-0.53 \mathrm{wt} . \%$ $\mathrm{MnO}$, with a mean of 0.38 wt. $\%$ and show a correlation with the bulk rock composition (Fig. 7). Manganese contents are within the broad range of magmatic olivines of Simkin and Smith (1970) relative to their iron content. In contrast, metamorphic olivines formed through serpentineout reactions tend to be much more Mn-rich (Frost 1975, Vance and Duncan 1977, Pincent and Hirst 1977) and have clear positive $\mathrm{Mn}-\mathrm{Fe}$ correlation.

Ca concentrations of metamorphic olivines are a function of $\mathrm{Ca}$ contents in the olivine precursor phyllosilicates and the distribution coefficients between metamorphic phases. Calcium

Table 4. Correlation matrix for cation content of porphyroblastic olivines. Analyses were presented in table 3.

\begin{tabular}{|c|c|c|c|c|c|}
\hline & $\mathrm{Fe}$ & $\mathrm{Mg}$ & $\mathrm{Mn}$ & $\mathrm{Ni}$ & Fo \\
\hline $\mathrm{Fe}$ & 1 & & & & \\
\hline $\mathrm{Mg}$ & -.984 & 1 & & & \\
\hline $\mathrm{Mn}$ & .584 & -.587 & 1 & & \\
\hline $\mathrm{Ni}$ & .770 & -.809 & .599 & 1 & \\
\hline Fo & -.997 & .994 & -.587 & -.789 & 1 \\
\hline
\end{tabular}


Fig. 7. Variation of $\mathrm{MnO}$ in porphyroblastic olivines with bulk rock $\mathrm{MnO}$ content. Error bars define empirical analytical errors.

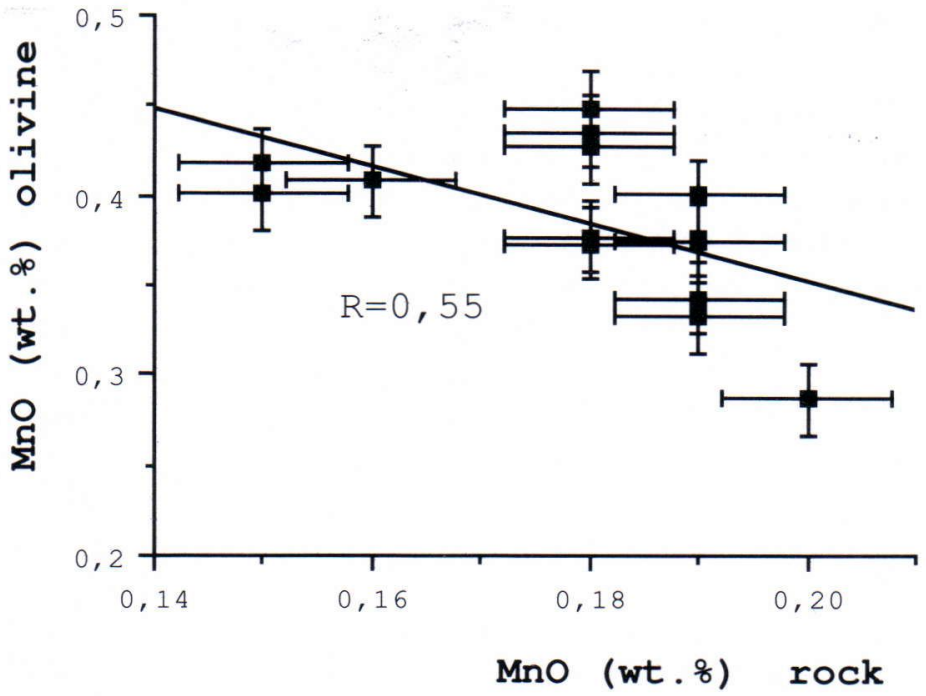

and Smith (1970), a correlation between Ca content and crystallization environment was found for magmatic olivines as a consequence of the fact that the solubility of $\mathrm{Ca}$ in forsterite coex-

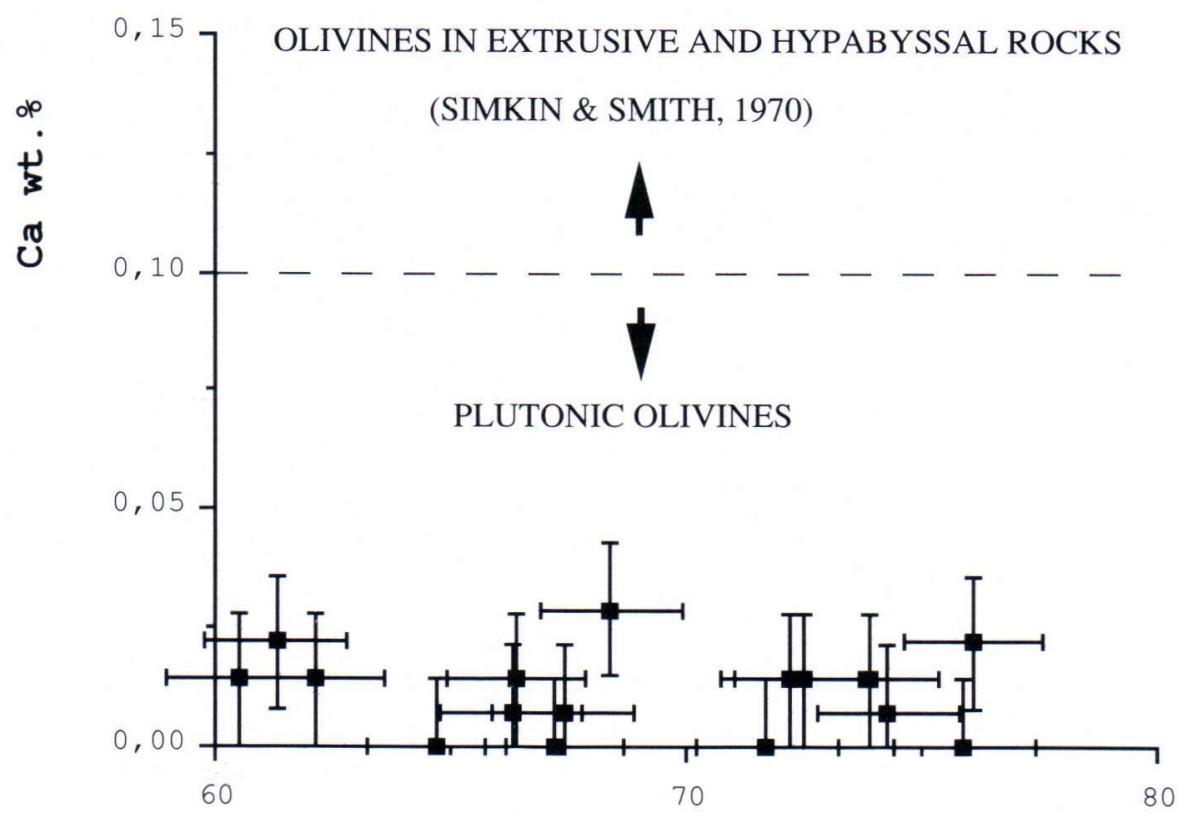

Fo (mol. $\left.\frac{8}{8}\right)$

Fig. 8. Variation of $\mathrm{Ca}$ with forsterite in porphyroblastic olivines. Analyses with calcium concentrations below the detection limit are shown on the base line of the graph. 
isting with orthopyroxene and clinopyroxene strongly decreases with increasing pressure (Adams and Bishop 1986). Plutonic olivines characteristicly contain $<0.1 \mathrm{wt} . \% \mathrm{Ca}$ while extrusive and hypabyssal olivines contain more. The Ca levels of the porphyroblastic olivines are similar to those in plutonic igneous olivines (Fig. 8).

\section{Discussion}

\section{$\mathrm{Fe}-\mathrm{Mg}$ distribution}

The iron-rich nature of porphyroblastic olivine in the Svecofennian metapicritic rocks is exceptional. Olivine composition depends on bulk rock composition as expected (Fig. 9), but not even in the most magnesian host rock does the forsterite content exceed $76 \mathrm{~mol} . \%$. The amount of metamorphic olivine in magnesian metavolcanics has been reported to correlate positively with bulk rock $\mathrm{MgO}$ contents (Hill et al. 1988). This seems to be valid also for the Svecofennian rocks. In the Vammala nickel belt where rock units exhibit differentiation within single flows, metamorphic olivine occurs exclusively in the most magnesian bottom units. Also the Fo content of the porphyroblasts correlates positively with $\mathrm{MgO}$ of the bulk rock. It follows that the more metamorphic olivine in the rock the more magnesian it is. However, Svecofennian metapicritic rocks are very magnesian and bulk rock compositions can not explain the overall Fe-rich nature of porphyroblasts.

In addition to bulk rock composition controls on metamorphic olivine composition, the nature of olivine protolith mineralogy is crucial. If serpentine had been the dominant premetamorphic alteration product of igneous olivine and other $\mathrm{Fe}-\mathrm{Mg}$ minerals, deserpentinization reactions during prograde metamorphism would have produced very magnesian olivine. This is due to the very iron-poor composition of serpentine formed from olivine (e.g. Duncan 1979, Wicks and Plant 1979) and the formation of magnetite from the excess iron (e.g. Evans 1977). Mineral assemblages and the subsolidus reactions deduced from them (see above) showed that breakdown of chlorite rather than serpentine was responsible for the formation of porphyroblastic olivine in the Svecofennian metapicrites. Complete solid solution exists between clinochlore $(\mathrm{Mg}$ endmember) and chamosite $\left(\mathrm{Fe}^{2+}\right.$ end-member) (Bailey 1988). Significantly, no magnetite necessarily formed when igneous pyroxenes, glassy

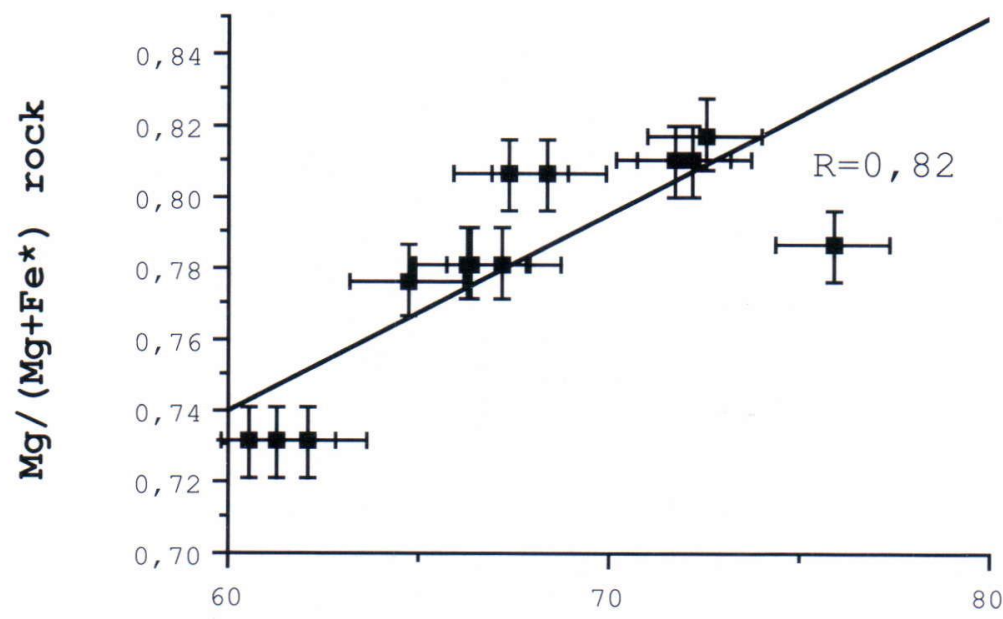

Fo (mol. $\left.\frac{8}{8}\right)$
Fig. 9. Relationship between forsterite content of porphyroblastic olivines and bulk rock $\mathrm{Mg} /\left(\mathrm{Mg}+\mathrm{Fe}^{*}\right)$ ratio. $\mathrm{Fe}^{*}=$ total iron. 
groundmass and olivine altered to chlorite. Chlorite could have also been produced by earlier, unrecognized metamorphic events. The $\mathrm{Fe} /$ $(\mathrm{Fe}+\mathrm{Mg})$ ratio $\left(\mathrm{X}_{\mathrm{Fe}}\right)$ of chlorite in ultramafic bodies readily increases as a result of metasomatic exchange of $\mathrm{Fe}$ and $\mathrm{Mg}$ between metamorphosed ultramafic rocks and the country rock (Zhong et al. 1985). If iron partitioned preferentially into chlorite relative to the bulk rock, relatively $\mathrm{Fe}$-rich metamorphic olivine could have been formed by chlorite breakdown during prograde metamorphism associated with the Svecokarelidic orogeny. According to McOnie (1975), intermediate $\mathrm{Fe}-\mathrm{Mg}$ chlorite on the clinochlore-chamosite join with $\mathrm{Fe} /(\mathrm{Fe}+\mathrm{Mg})$ between $0.35-0.53$ decomposes to olivine + cordierite + hercynite $\left(\mathrm{P}_{\mathrm{H} 2 \mathrm{O}}=2 \mathrm{~kb}, \mathrm{Ni}-\mathrm{NiO}\right.$ buffer). At higher pressures $(\mathrm{Mg}, \mathrm{Fe})$ olivine (Mg,Fe)orthopyroxene - hercynite may form.

\section{Nickel}

The observed negative correlation between $\mathrm{OL}^{\mathrm{Ni}}$ and $\mathrm{Fo}$ is an expected consequence if there were no co-existing $\mathrm{Ni}$-rich phases such as talc or sulfide. In these rocks the order of preference of $\mathrm{Ni}$ in minerals is olivine $>$ amphibole $>$ clinopyroxene $>$ orthopyroxene (Trommsdorff and Evans 1974). The more magnesian the host rock is the more olivine forms and the more magnesian the olivine is. Simultaneously the nickel content of this olivine decreases as a result of the larger modal abundance of olivine formed, thereby generating a negative $\mathrm{OL}^{\mathrm{Ni}}$-Fo correlation. Bulk rock MgO-OL ${ }^{\mathrm{Ni}}$ correlation is linear $(r=0.720)$. This process alone is able to explain the tenfold decrease observed in $\mathrm{OL}^{\mathrm{Ni}}$. OL $\mathrm{OL}^{\mathrm{Ni}}$ does not correlate with bulk rock nickel nor does $\mathrm{OL}^{\mathrm{Ni}}$ show significant negative correlation with bulk rock sulfur (Fig. 10). Even in rocks with very low sulfur contents, the range in $\mathrm{OL}^{\mathrm{Ni}}$ is very large. In Svecofennian metapicritic rocks, a sulphide phase did not play an important role in partitioning nickel due to the very small amount present. However, in sulfide-rich samples a regular partitioning of $\mathrm{Fe}$ and $\mathrm{Ni}$ between metamorphic serpentine derived olivine and bulk sulfide fraction has clearly been documented (Binns and Groves 1976, Papunen pers. comm.).

Very high Ni contents of some of the olivine porphyroblasts requires that premetamorphic serpentinization was not significant and $\mathrm{Ni}$ has not partitioned into oxides and sulphides - a process favored by low water fugacity during serpentinization (Wicks and O'Hanley 1988). Increasing serpentine to chlorite ratios resulted in the
Fig. 10. Variation of nickel in porphyroblastic olivines with bulk rock sulfur content.

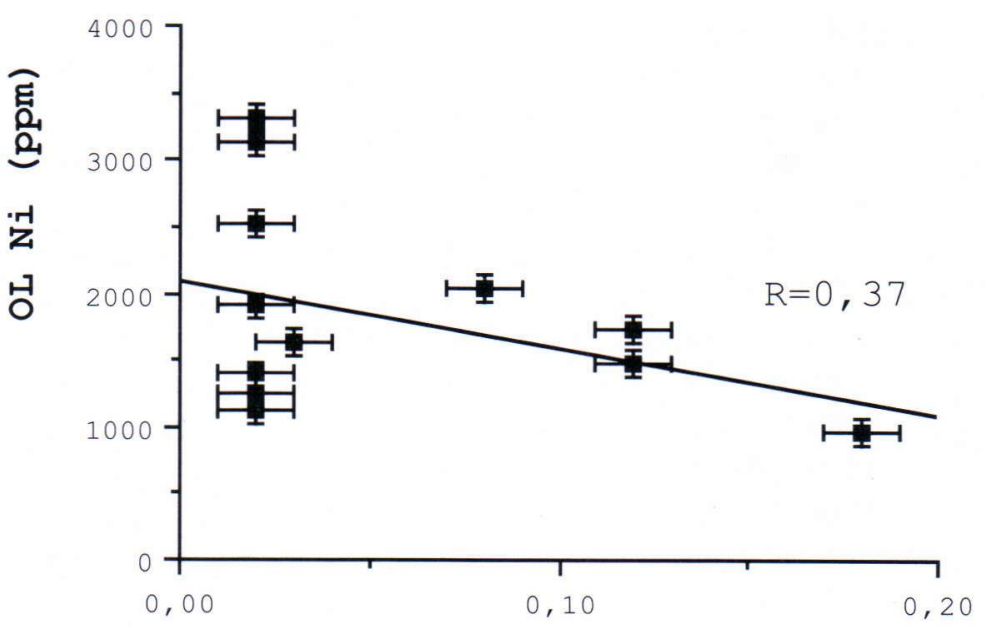

S (wt. o r) rock 
crystallization of more magnesian metamorphic olivine and greater Ni-partitioning into other phases than silicates. However, overall the proportion of serpentine was small and its presence had only a minor effect on $\mathrm{Ni}$ partioning. Weathering of serpentine minerals is able to increase their Ni content at the expence of $\mathrm{Mg}$ cations (Colightly and Arancibia 1979). Similar processes might have affected chlorite in extrusive Svecofennian metapicrites and improved the generation of negative OL ${ }^{\mathrm{Ni}}$-Fo correlations and low Fo contents exhibited by the olivine porphyroblasts.

\section{Conclusions}

The major conclusions of this study are:

1. Olivine in Svecofennian metapicritic rocks is metamorphic in origin. Subsolidus reactions deduced from stable mineral assemblages suggest that olivine formed through decomposition of chlorite-dominated hydrous phyllosilicates.

2. Generally, the metamorphic origin of olivine is evident in mineral textures. However, conclusions regarding the origin made from a single electron probe analyses can be erroneous. On the basis of a relatively small population, however, magmatic and metamorphic origins can be distinguished. Olivines formed through decomposition of chlorite yield compositional trends distinguishable from those of igneous olivines or metamorphic serpentine derived olivines. Metamorphic aluminous spinel (pleonasts) formed together with olivine porphyroblasts. Its presence can be utilized to identify metamorphic olivines formed through decomposition of chlorite.

3. The metamorphic olivines analyzed are anomalously $\mathrm{Fe}_{2} \mathrm{SiO}_{4}$-rich relative to their host rock compositions. Forsterite contents were governed by the bulk rock composition, the mineralogy of olivine precursor phyllosilicates, and metasomatic alteration and possible weather- ing of phyllosilicates during their pre-breakdown metamorphic history. The relative importance of these processes operating can be estimated only semiquantitively.

4. The very large range in the olivine nickel contents is striking in the Svecofennian metapicritic rocks. Olivine precursor minerals have been a mixture of alteration products of pyroxene, olivine and glassy groundmass and their earlier metamorphic derivatives. Modal increase in metamorphic olivine with increasing $\mathrm{MgO}$ contents of the bulk rock, varying chlorite/serpentine ratios and possible weathering of olivine precursor phyllosilicates are responsible for the negative $\mathrm{OL}^{\mathrm{Ni}}$-Fo correlations of metamorphic olivine. Only an insignificant proportion of nickel originally in the primary silicates has partitioned to other phases than silicates.

5. The "normal» manganese levels in these metapicrite olivines do not support significant involvement of deserpentinization reactions in their formation. The calcium concentrations in these olivine porphyroblasts are the same as those characteristic for plutonic igneous rocks.

6. In the Vammala nickel belt, metamorphic olivine together with metamorphic green spinel occur exclusively in barren metapicritic bodies (»cortlandites»).

7. Compositional trends of metamorphic olivines are significantly different from those of igneous ones. Great caution is emphasized when utilizing nickel in non-cumulate olivine for exploration purposes in metamorphosed terrains.

Acknowledgements. This paper is a contribution to »Global Geoscience Transect Program» and was financed by the Geological Survey of Finland and the Academy of Finland. Outokumpu Ltd provided part of the sample material and my thanks are due to Leo Grundström (Exploration Division) and Heikki Saarnio and Olli-Pekka Isomäki (Vammala Mine). Dr. Kalevi Korsman, Professor Atso Vorma, Professor Heikki Papunen and Dr. Hugh O'Brien reviewed the paper critically and with enthusiasm. 


\section{References}

Adams, G.E. \& Bishop, F.C., 1986. The olivine-clinopyroxene geobarometer: experimental results in the $\mathrm{CaO}-\mathrm{FeO}-\mathrm{MgO}-$ $\mathrm{SiO}_{2}$ system. Contrib. Mineral. Petrol. 94, 230-237.

Alapieti, T. \& Sivonen, S.J., 1983. Use of electron microprobe in the investigation of the early Proterozoic Koillismaa layered igneous complex, NE Finland. Geol. Surv. Finland Rep. Invest. 61.

Bailey, S. W., 1988. Chlorites: structures and crystal chemistry. In: Hydrous phyllosilicates (ed: Bailey, S.W.), Min. Soc. Am. Rev. Mineral. 19, 347-403.

Bickle, M.J., 1982. The magnesium contents of komatiitic liquids. In: Komatiites (eds: Arndt, N.T. \& Nisbett, E.G.). Allen \& Unwin, London, 479-494.

Binns, R.A. \& Champness, P.E. , 1985. Analytical electron microscopy study of red-brown olivines in ultramafic rocks from the Yilgarn block, W.A. CSIRO Division Mineralogy and Geochemistry Research Review 1985. CSIRO, Canberra, 32-33.

Binns, R.A. \& Groves, D.I., 1976. Iron-nickel partition in metamorphosed olivine-sulfide assemblages from Perseverance, Western Australia. Am. Min. 61, 782-787.

Blais, S. \& Auvray, B., 1990. Serpentinization in the Archean Komatiitic rocks of the Kuhmo greenstone belt, Eastern Finland. Can. Min. 28, 55-66.

Brown, G.E.Jr., 1980. Olivines and silicate spinels. In: Orthosilicates (ed.) P.H Ribbe, Min. Soc. Am. Rev. Min. 5, 275-379.

Collerson, K.D. \& Jesseau, C.W., 1976. Contrasting types of bladed olivine in ultramafic rocks from the Archean of Labrador. Can. J. Earth Sci. 13, 442-450.

Duke, J.M. \& Naldrett, A.J., 1978. A numerical model of the fractionation of olivine and molten sulfide from komatiite magma. Earth Planet. Sci. Lett. 39, 255-266.

Duncan, M.A., 1979. A microprobe study of antigorite and some serpentine pseudomorphs. Can. Min. 17, 771-784.

Dymek, R.F., Boak, J.L. \& Brothers, S.C., 1988. Titanian chondrodite- and titanian clinohumite-bearing metadunite from the $3800 \mathrm{Ma}$ Isua supracrustal belt, West Greenland: Chemistry, petrology, and origin. Am. Min. 73, 547-558.

Evans, B.W., 1977. Metamorphism of alpine peridotite and serpentine. Ann. Rev. Earth Planet. Sci. 5, 397-447.

Evans, B.W., 1982. Amphiboles in metamorphosed ultramafic rocks. In: D.R. Veblen \& P.H. Ribbe (eds.) Amphiboles: petrology and experimental phase relations. Min. Soc. Am. Rev. Min. 9B, 98-112.

Evans, B.W. \& Tromsdorff, V., 1974. On elongate olivine of metamorphic origin. Geology 2, 131-132.

Fawcett, J.J. \& Yoder, H.S., 1966. Phase relationships of chlorites in the system $\mathrm{MgO}-\mathrm{Al}_{2} \mathrm{O}_{3}-\mathrm{SiO}_{2}-\mathrm{H}_{2} \mathrm{O}$. Am. Min. $51,353-380$.

Frost, B.R., 1975. Contact metamorphism of serpentine, chloritic blackwall and rodingite at Paddy-Go-Easy Pass, Central Cascades, Washington. J. Petrol. 16, 272-313.
Gaál, G., 1990. Tectonic styles of early Proterozoic ore deposition in the Fennoscandian shield. Precambrian Res. 46, 83-114.

Golightly, J.P. \& Arancibia, O.N., 1979. The chemical composition and infrared spectrum of nickel- and ironsubstituted serpentine from a nickeliferous laterite profile, Soroako, Indonesia. Can. Min. 17, 719-728.

Häkli, T.A., Vormisto, K. \& Hänninen, E., 1979. Vammala, a nickel deposit in layered ultramafite, southwestern Finland. Econ. Geol. 74, 1166-1182.

Hietanen, A., 1976. Blades of olivine in ultramafic rock from northern Sierra Nevada, California. J. Research. U.S. Geol. Surv. 5/2, 217-219.

Hill, R.E.T., Cole, M.J. \& Barnes, S.J., 1988. Physical volcanology of komatiites. A field guide to the komatiites between Kalgoorlie and Wiluna, Eastern Goldfields Province, Yilgarn Block, Western Australia. Excursion Guide Book No. 1. CSIRO, Division of Minerals and Geochemistry, Perth, 74 p.

Huhma, H., 1986. Sm-Nd, U-Pb and $\mathrm{Pb}-\mathrm{Pb}$ isotopic evidence for the origin of the Early Proterozoic Svecokarelian crust in Finland. Geol. Surv. Finland Bull. 337, 48 p.

Jenkins, D.M., 1981. Experimental phase relations of hydrous peridotites modelled in the system $\mathrm{H}_{2} \mathrm{O}-\mathrm{CaO}-\mathrm{MgO}$ $\mathrm{Al}_{2} \mathrm{O}_{3}-\mathrm{SiO}_{2}$. Contrib. Mineral. Petrol. 77, 166-176.

Jenkins, D.M. \& Chernosky, J.V.Jr., 1986. Phase equilibria and crystallochemical properties of $\mathrm{Mg}$-chlorite. Am. Min. 71, 924-936.

Kähkönen, Y., 1989. Geochemistry and petrology of the metavolcanic rocks of the early Proterozoic Tampere schist belt, southern Finland. Geol. Surv. Finland Bull. 345, 107 p.

Korsman, K., 1977. Progressive metamorphism of the metapelites in the Rantasalmi-Sulkava area, southeastern Finland. Geol. Surv. Finland Bull. 290, 82 p.

Kousa, J., 1985. Tholeiitic and komatiitic volcanism in the Rantasalmi area (in Finnish with English abstract). Geologi 37, 18-22.

Kunugiza, K., 1982. Formation of zoning of olivine with progressive metamorphism of serpentine - an example from the Ryomon peridotitte body of the Sanbagawa metamorphic belt, Kii peninsula. J. Japan. Assoc. Min. Petr. Econ. Geol. 77, 157-170.

Le Maitre, R.W. (ed.), 1989. A classification of igneous rocks and glossary of terms. Recommendations of the IUGS subcommission on the systematics of igneous rocks. Blackwell Scientific Publications.

Lieberman, J.E. \& Rice, J.M., 1986. Petrology of marble and peridotite in the Seiad ultramafic complex, northern California, USA. J. Metamorphic Geol. 4, 179-199.

Mäkelä, U., 1989. Geological and geochemical environments of Precambrian sulphide deposits in southwestern Finland. Ann. Acad. Sci. Fenn. Ser. A (III), 151, 102 pp. Mäkinen, J., 1987. Geochemical characteristics of Svecokare- 
lidic mafic-ultramafic intrusions associated with $\mathrm{Ni}-\mathrm{Cu}$ occurrences in Finland. Geol. Surv. Finland Bull. 342, $109 \mathrm{pp}$.

McOnie, A. W., Fawcett, J. J. \& James, R.S., 1975. The stability of intermediate chlorites of the clinochlore-daphnite series at 2 kbar $\mathrm{P}_{\mathrm{H} 2 \mathrm{O}}$. Am. Min., 1047-1062.

Mercier, J.C. \& Nicolas, A., 1975. Textures and fabrics of upper mantle peridotites as illustrated by basalt xenoliths. J. Petrol. 16, 454-487.

Nilsson, G., 1985. Nickel-copper deposits in Sweden. In: H. Papunen \& G.I. Gorbunov (eds.): Nickel-copper deposits of the Baltic Shield and Scandinavian Caledonides. Geol. Surv. Finland Bull. 333, 313-362.

Nironen, M., 1989. Emplacement and structural setting of granitoids in the early Proterozoic Tampere and Savo Schist Belts, Finland - implications for contrasting crustal evolution. Bull. Geol. Surv. Finland 346, 83 pp.

Oliver, R.L., Nesbitt, R.W. \& Hausen, D.M., 1972. Metamorphic olivine in ultramafic rocks from Western Australia. Contrib. Mineral. Petrol. 36, 335-342.

Paktunç, A.D., 1984. Metamorphism of the ultramafic rocks of the Thompson mine, Thompson nickel belt, northern Manitoba. Can. Min. 22, 77-91.

Papunen, H. \& Idman, H., 1982. Ultramafic rocks and related ore minerals in Lapland, Northern Finland. In: G.C. Amstutz, A. El Goresy, G. Frenzel, C. Kluth, G. Moh, A.Wauschkuhn \& R.A. Zimmermann (eds.). Ore genesis - the state of art. Springer-Verlag, Berlin, Heidelberg, 374-386.

Parras, K., 1958. On the charnockites in the light of a highly metamorphic rock complex in southwestern Finland. Bull. Comm. geol. Finlande 181, 137 p.

Peltonen, P. \& Korsman, K., 1990. Metamorphism of ultramafic rocks in the early Proterozoic Svecofennian nickel province - implications for the timing of emplacement of Ni-Cu ores hosting intrusive bodies (Abstract). \Second Baltic Shield Symposium». Lund, Sweden 5.-7. 6. 1990, p. 71.

Peretti, A., Trommsdorff, V. \& Frost, B.R., 1987. Reactions governing the appearance of olivine in the Malenco serpentinite, northern Italy. Geol. Soc. Am. Abstr. Programs 19, p. 802.

Pincent, R.H. \& Hirst, D.M., 1977. The metamorphism of the Blue River Ultramafic Body, Cassiar, British Columbia, Canada. J. Petrol. 18, 567-594.

Rajamani, V., Brown, G.E. \& Prewitt, C.T., 1975. Cation ordering in Ni-Mg olivine. Am. Min. 60, 292-299.

Roeder, P.L. \& Emslie, R.F., 1970. Olivine-liquid equilibrium. Contrib. Mineral. Petrol. 29, 275-289.

Schreurs, J. \& Westra, L., 1986. The thermotectonic evolution of a Proterozoic, low pressure, granulite dome, WestUusimaa, SW Finland. Contrib. Mineral. Petrol. 93, $236-250$.
Schreurs, J., van Kooperan, P. \& Westra, L., 1986. Ultramafic metavolcanic rocks of early Proterozoic age in WestUusimaa, SW Finland. Neues Jahrbuch Miner. Abh. 155, 185-201.

Simkin, T. \& Smith, J.V., 1970. Minor-element distribution in olivine. J. Geol. 78, 304-325.

Simonen, A., 1980. The Precambrian of Finland. Geol. Surv. Finland Bull. 304, 58 pp.

Stamatelopoulou-Seymour, K. \& Francis, M.F., 1980. Metamorphic olivine in peridotiitic komatiite flows, Lac Guyer, Québec. Can. Min. 18, 265-270.

Snoke, A.W. \& Calk, L.C., 1978. Jackstraw-textured talcolivine rocks, Preston Peak area, Klamath Mountains, California. Geol. Soc. Am. Bull. 89, 223-230.

Thompson, J.F.H. \& Naldrett, A.J., 1984. Sulfide-silicate reactions as a guide to $\mathrm{Ni}-\mathrm{Cu}-\mathrm{Co}$ mineralization in central Maine. In: D.L. Buchanan \& M.J. Jones (eds.). Sulfide Deposits in Mafic and Ultramafic Rocks, Inst. Min. Metall. Special Publ., London, 103-113.

Trommsdorff, V. \& Evans, B.W., 1974. Alpine metamorphism of peridotitic rocks. Schweitz. Mineral. Petrol. Mitt. 54, 333-352

Turnock, A.C., 1960. The stability of iron chlorites. Garnegie Inst. Washington Year Book 59, 98-103.

Vaasjoki, M. \& Huhma, H., 1987. Led isotopic results from metabasalts of the Haveri formation, southern Finland: an indication of early Proterozoic mantle derivation. Terra Cognita 7, p. 159.

Vance, J.A. \& Duncan, M.A., 1977. Formation of peridotites by deserpentinization in the Darrington and Sultan areas, Cascade Mountains, Washington. Geol. Soc. Am. Bull. 88, 1497-1508.

Warner, R.D., Griffin, V.S., Steiner, J.C., Schmitt, R.A. \& Bryan J.G., 1989. Ultramafic chlorite-tremolite-olivine schists: Three bodies from the Inner Piedmont belt, South Carolina. Geol. Soc. Am. Spec. Pap. 231, 63-74.

Wicks, F.J., Whittaker, E.J.W. \& Zussman, J., 1977. An idealized model for serpentine textures after olivine. Can. Min. 15, 446-458.

Wicks, F.J. \& Plant, A.G., 1979. Electron-microprobe and $\mathrm{X}$-ray-microbeam studies of serpentine textures. Can. Min. 17, 785-830.

Wicks, F.J. \& O'Hanley D.S., 1988. Serpentine minerals: structures and petrology. In: S.W.Bailey (ed.). Hydrous phyllosilicates. Min. Soc. Am. Rev. Mineral. 19, 91-167.

Zhong, W.S.J., Hughes, J.M. \& Scotford, D.M., 1985. The response of chlorite to metasomatic alteration in Appalachian ultramafic rocks. Can. Min. 23, 443-446.

Received April 27, 1990

Revision accepted September 21, 1990 